\title{
THE BIOSYNTHESIS AND TURNOVER OF OXALATE IN NORMAL AND HYPEROXALURIC SUBJECTS *
}

\author{
By T. DAVID ELDER AND JAMES B. WYNGAARDEN \\ (From the Department of Medicine, Duke University Medical Center, Durham, N. C.)
}

(Submitted for publication February 10, 1960; accepted March 31, 1960)

Oxalate is a normal constituent of human urine. Since oxalate is found in many foods it has frequently been assumed that urinary oxalate is largely, if not entirely, of dietary origin. However, animal studies have shown that oxalate may arise endogenously, and glycine, glyoxylic acid, glycolic acid (3-5) and ascorbic acid $(6,7)$ have been shown to be precursors of urinary or tissue oxalate under various circumstances.

The origin of urinary oxalate has long been an important physiological problem because of the high incidence of calcium oxalate urolithiasis in many parts of the world. Recently, interest in the biosynthesis of oxalate in man has been greatly stimulated by recognition of the syndrome of primary hyperoxaluria and oxalosis, a disorder in which excessive production of oxalate occurs and leads to deposition of calcium oxalate crystals in renal parenchyma and extrarenal tissues. Ascorbic acid has previously been shown to be a pre- cursor of some urinary oxalate of normal man $(6,8)$. In this paper glycine is shown to be a major precursor of urinary oxalate of normal and hyperoxaluric subjects. In one subject with primary hyperoxaluria, glycine incorporation into urinary oxalate was excessive, whereas in another subject with an inconstant hyperoxaluria, glycine incorporation was not abnormal. Measurements of the miscible pool of oxalate and of the rate of its turnover have been made by conventional isotopic dilution techniques, and a gross expansion of the miscible pool of oxalate demonstrated in a hyperoxaluric subject.

\section{EXPERIMENTAL METHODS}

Materials. Glycine $1-\mathrm{C}^{14}$, specific activity $2.2 \mathrm{mc}$ per mmole, and oxalic acid $1,2-\mathrm{C}^{14}$, specific activity $2.6 \mathrm{mc}$ per mmole, both of radiopurity $>99$ per cent, were purchased from Isotopes Specialties Co. Burbank, Calif.

Control subjects. Control subjects were hospitalized

* Supported in part by a grant (A-1391) from the United States Public Health Service. Preliminary reports of this work have appeared $(1,2)$. patients without known metabolic, gastrointestinal or genitourinary disease, in whom routine tests [urinalysis, blood urea nitrogen (BUN), phenolsulfonphthalein (PSP) excretion] disclosed no evidence of renal disease. They were permitted a regular hospital diet except that foods of high oxalate content [cocoa, chocolate, tea, rhubarb, beets and spinach (9)] were withheld for a few days before and during the study period. The basal excretion of oxalate [as $(\mathrm{COOH})_{2} \cdot 2 \mathrm{H}_{2} \mathrm{O}$ ] ranged from 11.6 to $36.0 \mathrm{mg}$ per day in the control subjects.

Hyperoxaluric subjects. C.B. was a 30 year old male who was first seen at Duke Hospital in 1950 at the age of 23. He had had recurrent urolithiasis since age 10 and had required pyelolithotomy at ages 18 and 19 . On admission in 1950 nephrolithotomy and pyelolithotomy were again performed, urinary tract infection was present and the stones were found to contain calcium, oxalate, phosphate and small amounts of carbonate. Subsequent to 1950 he required litholapaxy on several occasions. $\mathrm{He}$ passed gravel almost daily, and had severe renal colic on numerous occasions each month. Repeated analyses of serum calcium, phosphorus and alkaline phosphatase were normal. Mild elevations of nonprotein nitrogen (NPN) (maximum, $60 \mathrm{mg}$ per $100 \mathrm{ml}$ ), serum uric acid (maximum, $6.2 \mathrm{mg}$ per $100 \mathrm{ml}$ ) and cholesterol $(268 \mathrm{mg}$ per $100 \mathrm{ml}$ ) were noted, and PSP excretion tests ranged from 41 to 45 per cent in 2 hours. Urine cultures revealed organisms of the Klebsiella and Aerobacter groups, and he was treated with various agents without success.

In 1958 he was found to be excreting abnormal quantities of oxalate, ranging from 103 to $143 \mathrm{mg}$ per day. He was therefore admitted for further study. General physical examination was normal except for well healed surgical scars. Blood pressure was $114 / 80$. Urinalysis revealed $\mathrm{pH} 6.5$, specific gravity 1.011 , a trace of protein, and innumerable leukocytes in the sediment. NPN was 48, serum uric acid 6.8 , calcium 9.3 , and phosphorus 3.5 mg per $100 \mathrm{ml}$. X-ray revealed bilateral staghorn calculi but no evidence of nephrocalcinosis. $\mathrm{He}$ was placed on a diet calculated to contain $62 \mathrm{mg}$ of oxalate daily during the study period.

A familial history of urolithiasis was obtained, and a sister was found also to have a slightly elevated urinary excretion of oxalate (65 mg per day). This sister has passed stones composed of calcium oxalate; both parents and a paternal cousin have also passed stones. The parents and a brother of the patient died of nonrenal disorders.

N.M., a 48 year old female with a 25 year history of recurrent calcium oxalate urolithiasis, was studied 4 
months following left nephrectomy. The kidney was nonfunctioning and showed chronic pyelonephritis and hydronephrosis but no nephrocalcinosis or parenchymal oxalate deposits. One week after operation her urinary oxalate excretion was $117 \mathrm{mg}$ per 24 hours; 4 months later when she was admitted for further studies it was initially $90 \mathrm{mg}$ per 24 hours. She was placed on a standard diet calculated to contain each day: protein $30.4 \mathrm{~g}$, calcium $112.5 \mathrm{mg}$, ascorbic acid $33 \mathrm{mg}$, pyridoxine 0.5 $\mathrm{mg}$. By analysis it contained $129 \mathrm{mg}$ of oxalic acid dihydrate per day. After 6 days on this diet her urinary calcium excretion was 400 to $600 \mathrm{mg}$ per day. Serum calcium was $9.1 \mathrm{mg}$ per $100 \mathrm{ml}$, phosphorus $4.2 \mathrm{mg}$ per $100 \mathrm{ml}$ and alkaline phosphatase $2.6 \mathrm{U}$ per $100 \mathrm{ml}$. Studies to date have not established the cause of her hypercalcuria. Because of a decline in hyperoxaluria while on the experimental diet, she remained on a $30 \mathrm{~g}$ protein regimen following the study. Urinary oxalate excretion has remained below $40 \mathrm{mg}$ per day on 3 different examinations over a 5 -month period. Her urine sediment is now free from calcium oxalate crystals, which were formerly present in abundance in all specimens.

Tracer studies. Glycine 1-C $\mathrm{C}^{\mathbf{1 4}}$ was administered orally to subjects in the fasting state in 25 or $50 \mu \mathrm{c}$ doses (11.4 or $22.7 \mu \mathrm{g}$ ) in $100 \mathrm{ml}$ of water. Oxalic acid $1,2-\mathrm{C}^{14}$ was administered slowly intravenously in $1 \mu \mathrm{c}$ doses $(0.05 \mathrm{mg})$ in $2 \mathrm{ml}$ of sterile (Seitz-filtered) solution in water. Both compounds were administered after an overnight fast.

In two subjects oxalate and hippurate were isolated simultaneously, from successive 2-hour urine samples. Two hours after ingestion of labeled glycine, and at 4hour intervals for 3 additional doses, the subjects ingested $3 \mathrm{~g}$ of sodium benzoate, so as to insure a large urinary output of hippuric acid.

Urine specimens were collected in clean glass jugs containing $5 \mathrm{ml}$ of concentrated $\mathrm{HCl}$. Respiratory $\mathrm{CO}_{2}$ was collected in carbonate-free, $1 \mathrm{~N}$ sodium hydroxide and precipitated as barium carbonate.

All counting was done in stainless steel planchets in a Robinson gas-flow counter (10). Calcium oxalate samples varied in mass from 4 to $36 \mathrm{mg}$ and were corrected for self-absorption to a standard mass of $22 \mathrm{mg}$ per planchet $(1.54 \mathrm{sq} \mathrm{cm})$. Barium carbonate samples were counted in infinite thickness. Hippuric acid samples weighed from 5 to $15 \mathrm{mg}$ and were corrected for self-absorption to a standard mass of $3.3 \mathrm{mg}$ per planchet. Appropriate conversion factors were employed for comparison of counting values of glycine, oxalic acid, calcium oxalate and hippuric acid when required.

Isolation of oxalate from urine. Each urine sample was filtered through Whatman no. 42 paper in a Buchner funnel if any cloudiness or precipitate was grossly visible, and aliquots were taken for determination of oxalate by the method of Archer, Dormer, Scowen and Watts (11). Thirty $\mathrm{mg}$ of oxalic acid dihydrate was added to the remainder of each urine specimen as carrier and the volume reduced to approximately $20 \mathrm{ml}$ under reduced pressure at $30^{\circ} \mathrm{C}$. The $\mathrm{pH}$ was adjusted to 5.5 with $8 \mathrm{~N}$ ammonium hydroxide, and $5 \mathrm{ml}$ of 5 per cent $\mathrm{CaCl}_{2}$ was then added. The samples were stored at $4^{\circ} \mathrm{C}$ overnight, centrifuged, and the supernatant solution disçarded.
Calcium oxalate was then purified by a slight modification of the method of Burns, Burch and King (12). The precipitate was washed 2 or 3 times with $4 \mathrm{ml}$ of 0.35 $\mathrm{N} \mathrm{NH} \mathrm{NH}_{4} \mathrm{OH}$, to remove colored impurities, and dissolved in $6 \mathrm{ml}$ of $1 \mathrm{~N}$ sulfuric acid; after centrifugation the residue was discarded. The supernatant was placed in a glass microextractor ${ }^{1}$ and extracted continuously with $100 \mathrm{ml}$ of ether for at least 6 hours. At the end of the extraction period $10 \mathrm{ml}$ of distilled water was added to the flask and the ether evaporated on a steam bath. The aqueous phase was transferred to a $40 \mathrm{ml}$ conical centrifuge tube and the $\mathrm{pH}$ was adjusted to 5.5 with $8 \mathrm{~N}$ ammonium hydroxide. Calcium oxalate was reprecipitated by addition of $5 \mathrm{ml}$ of 5 per cent $\mathrm{CaCl}_{2}$. The sample was stored overnight in the cold, centrifuged, and the supernatant discarded. The precipitate was dissolved in $1 \mathrm{~N} \mathrm{HCl}$, treated with Darco, filtered, and recrystallized by adjustment of the $\mathrm{pH}$ to 5.5 and addition of $5 \mathrm{ml}$ of 5 per cent $\mathrm{CaCl}_{2}$. The last procedure was repeated several times.

The samples were dried at $80^{\circ} \mathrm{C}$ in a vacuum oven, ground with a stout glass rod in acetone, and transferred by pipet to a tared stainless steel planchet for counting.

Isolation of hippuric acid from urine. Urinary hippuric acid was isolated according to Quick (13) and purified by treatment with Darco and by repeated recrystallizations from hot water (14). The melting points of the isolated samples were identical with those of authentic hippuric acid.

Calculations. The standard isotopic dilution equation for calculating the miscible pool of oxalate is as follows (15) : $A=a\left(I_{1} / I_{0}-1\right)$, where $A$ is the size of the miscible pool, a is the quantity of labeled material added to the pool, $I_{i}$ is the specific activity of the injected material, and $I_{0}$ is the theoretical specific activity in the miscible pool at the moment of mixing. In the present study this equation was simplified, and the pool was calculated as follows: $\mathrm{A}=\left(\mathrm{aI}_{1}\right)^{\prime} / \mathrm{I}_{0}$. In this equation $\left(\mathrm{aI}_{1}\right)^{\prime}$ represents the total counts administered minus the labeled oxalate which was excreted too rapidly to have mixed thoroughly within the pool (see below). The term "- 1" of the first equation may be ignored, since "a" was very small $(0.05 \mathrm{mg})$ compared with values of $\mathrm{A}$ (4 to $8 \mathrm{mg}$ ). The intercept, $\mathrm{I}_{\mathrm{o}}$, and the slope, $-\mathrm{K}$, and their standard deviations, were calculated by the method of least squares. The biological half-time, $\mathrm{T}_{2}$, was obtained from the expression (15) $\mathrm{K}=\log 2 / \mathrm{T}_{\frac{1}{2}}$. The standard deviation of $\mathrm{A}$ was calculated as previously described (16).

\section{RESULTS}

\section{Oxalate excretion}

The urinary excretion of oxalate in 18 normal subjects ( 37 samples) on a mixed diet ranged from 6.3 to $44.8 \mathrm{mg}$, and averaged $22.1 \mathrm{mg}$ per 24 hours, [as oxalic acid dihydrate, $(\mathrm{COOH})_{2} \cdot 2 \mathrm{H}_{2} \mathrm{O}$ ]. No consistent diurnal variation was found in two

1 Ace Glass Co., Inc., Vineland, N. J., Catalog no. 6820. 


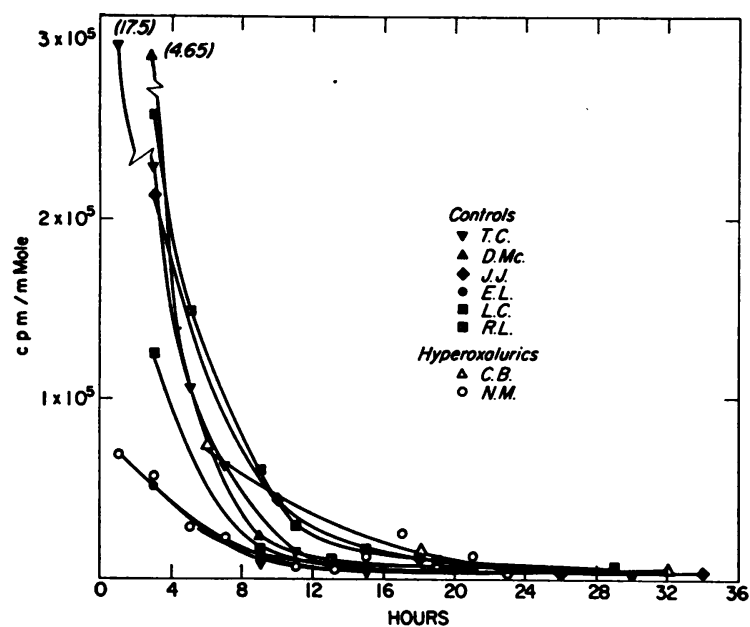

Fig. 1. INCORPORATION OF GLYCINE 1-C ${ }^{14}$ INTO URINARY OXALATE IN CONTROL AND HYPEROXALURIC SUBJECTS The data have been normalized to a standard dose of $25 \mu \mathrm{c}$ of $\mathrm{C}^{14}$, given orally as carrier-free glycine $1-\mathrm{C}^{14}$.

subjects in each of whom 12 consecutive 8-hour collections were obtained, nor was urinary oxalate excretion significantly correlated with urine volume $(R=0.87,0.68 ; p=0.06,0.20)$.

\section{Glycine incorporation}

Urinary oxalate became highly labeled within a few hours following oral administration of $25 \mu \mathrm{c}$ of glycine $1-\mathrm{C}^{14}$ in each of six control subjects (Figure 1). The initial (3-hour) specific activity values ranged from 49,000 to $450,000 \mathrm{cpm}$ per mmole. This ninefold range was found in subjects having only a threefold range in urinary

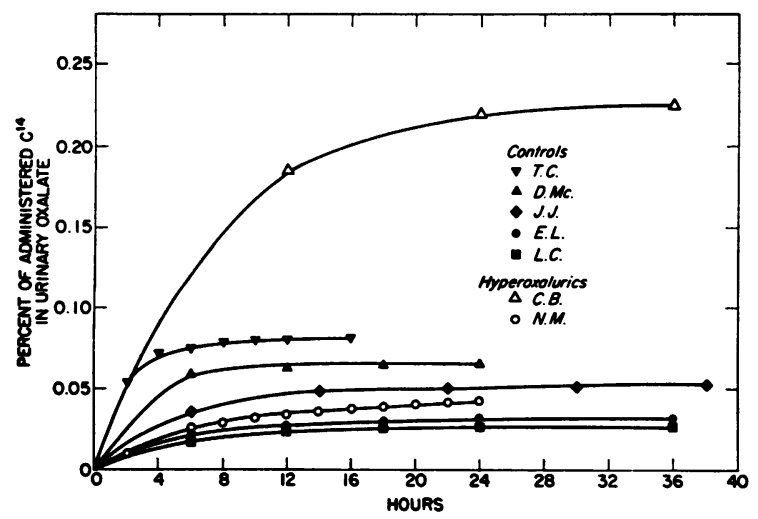

Fig. 2. Cumulative incorporation of glycine 1-C 14 INTO URINARY OXALATE IN CONTROL AND HYPEROXALURIC SUBJECTS. Data are expressed ins percentage of administered $\mathrm{C}^{14}$.

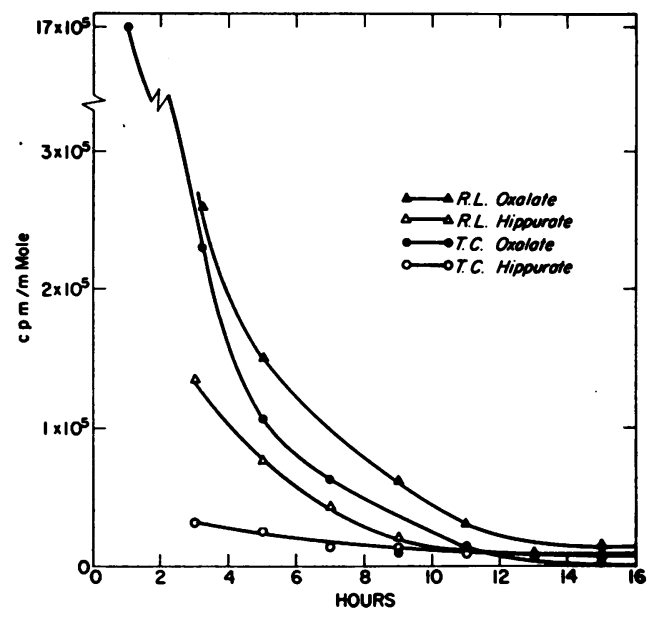

Fig. 3. COMParison OF ENRICHMENT OF URINARY OXALATE AND HIPPURATE IN TWO CONTROL SUBJECTS FOLLOWING INGESTION OF $25 \mu \mathrm{C}$ of GLYCINE $1-\mathrm{C}^{\mathbf{1 4}}$. Sodium benzoate, $3 \mathrm{~g}$, was given orally at $2,6,10$ and 14 hours to insure a large urinary output of hippurate.

oxalate values; specific activity values were not inversely correlated with excretion values. Enrichment values declined rapidly so that, by 24 to 30 hours, the counting values of urinary oxalate approached background.

The cumulative incorporation of $\mathrm{C}^{14}$ into urinary oxalate (Figure 2) ranged from 0.027 to 0.081 per cent (mean, 0.051 per cent) of the administered dose of glycine 1-C $\mathbf{C}^{\mathbf{1 4}}$ in five control subjects.

In two control subjects who received load doses of sodium benzoate beginning 2 hours after ingestion of glycine (Figure 3), urinary oxalate was significantly more highly labeled than was urinary hippurate between 2 and 10 hours. Both substances exhibited typical die-away enrichment curves in both subjects.

These studies establish that glycine serves as a precursor of at least some of the urinary oxalate in normal man, and suggest 1 ) that relatively little dilution occurs between glycine and oxalate, 2) that the miscible pool of oxalate is small, and 3) that the turnover of the oxalate pool is rapid. Measurements of the miscible pool of oxalate and of its turnover were then attempted by standard isotopic dilution techniques.

The miscible pool of oxalate and the rate of its turnover

When $50 \mu \mathrm{g}$ of oxalic acid 1,2-C $\mathrm{C}^{14}$ was injected intravenously into control subjects, a portion rap- 
idly appeared in urine. A semilogarithmic plot of specific activity of urinary oxalate against time showed that a linear decay was achieved after 4 hours (Figures 4, 5). After about 18 hours the specific activity values were so low that their accuracy was doubtful, and their usefulness small in this study.

By the time that mixing of the labeled oxalate within the oxalate pool was complete, presumably about 4 hours after its administration, a large fraction of the test dose of labeled oxalate had already been excreted. Since eventually 89 to 99 per cent of the administered tracer was recovered unchanged in urine (see below), nonrenal loss of oxalate was not an appreciable factor, and a correction for the labeled oxalate which had failed to mix adequately could be applied on the basis of the 0 to 4 hour urinary fraction. The regression of the linear portion of the specific activity-time curve was calculated by the method of least squares, omitting data of 0 to 2 and 2 to 4 hour points. In each case the zero intercept was a highly significant value, $\mathrm{p}<0.01$. The oxalate- $\mathrm{C}^{14}$ excreted in excess of that anticipated from the extrapolated curve was then subtracted from the administered dose $\left(\mathrm{aI}_{\mathrm{i}}\right)$ and further calculations were made on the basis of the "corrected administered dose" $\left(\mathrm{aI}_{\mathrm{i}}\right)^{\prime}$. The subtrahend averaged

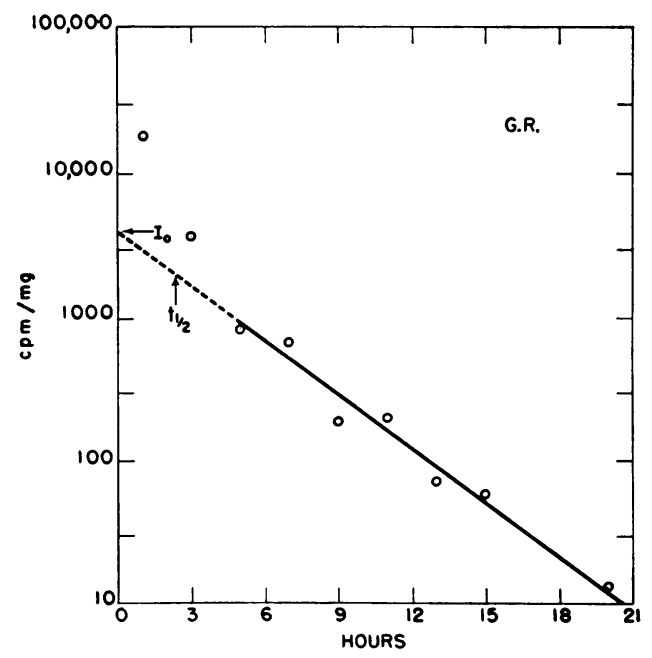

Fig. 4. Specific activity of Urinary oxalate folLOWING INTRAVENOUS ADMINISTRATION OF OXALIC ACID $1,2-\mathrm{C}^{14}$ to A CONTROL SUBJECT. The data of this experiment (Subject G.R., Table I), when analyzed by the method of least squares, indicated a miscible pool of $4.9 \pm$ $0.7 \mathrm{mg}$, and a turnover rate of $1.4 \pm 0.3 \mathrm{mg}$ per hour.

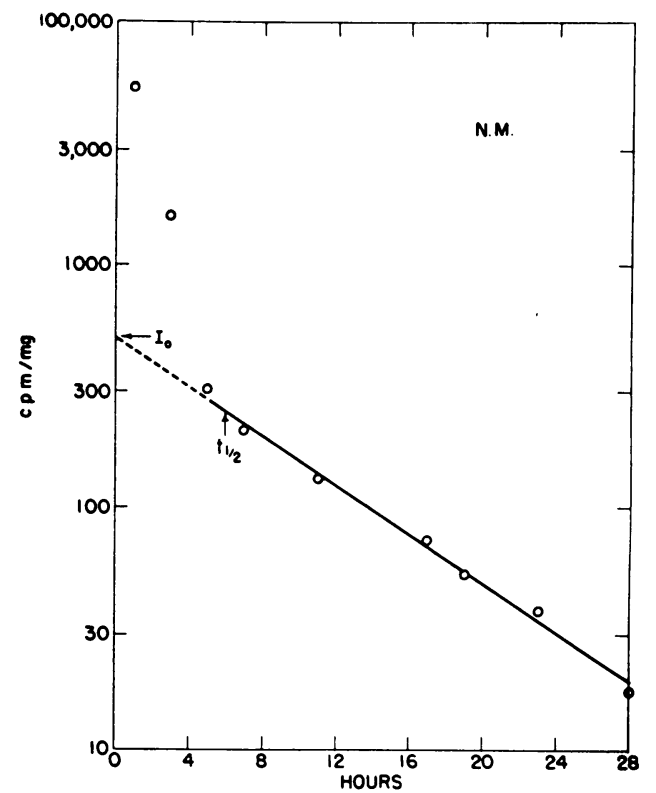

Fig. 5. Specific activity of URinary oxalate folLOWING INTRAVENOUS ADMINISTRATION OF OXALIC ACID 1,2-C $\mathrm{C}^{14}$ To A hyperoxaluric subject. These data (Subject N. M., Table I) indicated a miscible pool of $39.1 \pm$ $2.4 \mathrm{mg}$ and a turnover rate of $4.6 \pm 0.3 \mathrm{mg}$ per hour.

about 60 per cent of $\left(\mathrm{aI}_{\mathrm{i}}\right)$, and therefore the measurements of oxalate and of specific activity in the initial samples are critical to this correction.

Table I shows that the calculated miscible pool of oxalate (expressed as oxalic acid dihydrate) ranged from $4.9 \pm 0.7$ to $8.6 \pm 1.1 \mathrm{mg}$ in three control subjects. The biological half-time of the pool ranged from $2.2 \pm 0.3$ to $2.8 \pm 0.3$ hours. The calculated daily turnover of oxalate in these three control subjects ranged from $34.1 \pm 6.7$ to $63.8 \pm 11.3 \mathrm{mg}$ per day. In each case the value of urinary oxalate on the day of the study fell within $2 \mathrm{SD}$ of the calculated turnover.

\section{Physiological disposition of oxalate in man}

In three studies on control subjects and in two studies on N.M., a hyperoxaluric subject (see below), from 89 to 99 per cent of the injected oxalate $1,2-C^{14}$ was recovered unchanged in urine in 36 hours.

Respiratory $\mathrm{CO}_{2}$ was collected at frequent intervals for 6 hours from two control subjects who had received $1 \mu \mathrm{c}$ of oxalate- $\mathrm{C}^{14}$ intravenously and orally, respectively. In both cases all samples of $\mathrm{CO}_{2}$, counted as barium carbonate, were devoid 


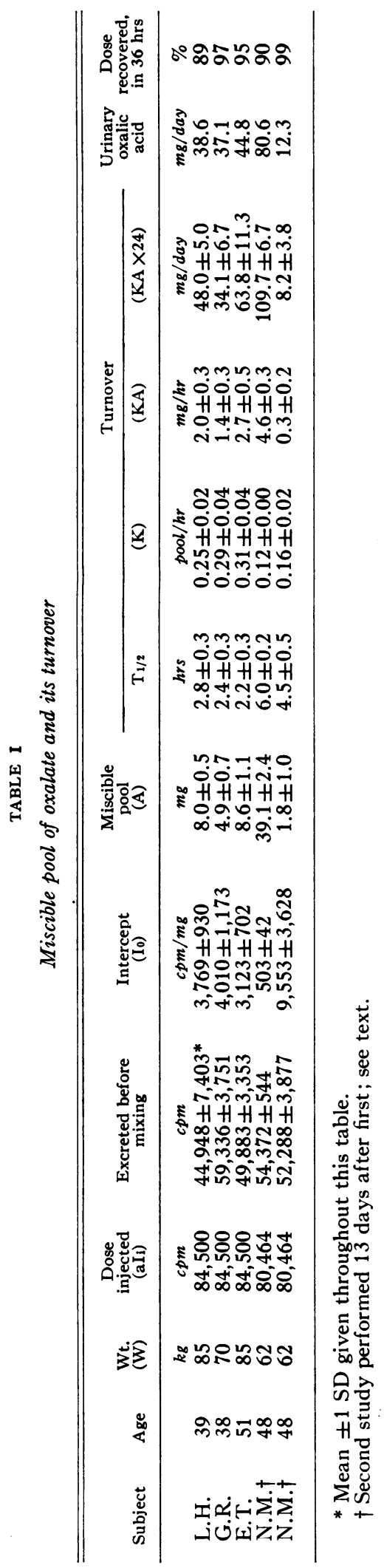

of enrichment by the counting method employed, which would have detected as little as 0.01 per cent of the administered dose in any single sample.

Studies on patients with hyperoxaluria and recurrent calcium oxalate urolithiasis

Subject $C$. B. The male subject with probable primary hyperoxaluria was given an oral dose of $25 \mu \mathrm{c}$ glycine $1-\mathrm{C}^{14}$, and incorporation of $\mathrm{C}^{14}$ into urinary oxalate was demonstrated. The specific activity values were comparable with those found in control subjects at equivalent points in time (Figure 1); however, a cumulative incorporation of 0.22 per cent of the administered dose was found (Figure 2), a value some fourfold greater than the mean cumulative incorporation value found in the control subjects.

Subject N.M. During the first week on the special diet the urinary oxalate excretion of N.M., the female hyperoxaluric subject, progressively declined, and after the seventh day it remained within the normal range. The factors involved in the disappearance of hyperoxaluria in this patient are not understood and are the subject of continuing studies which will be reported elsewhere. The studies with glycine $1-\mathrm{C}^{\mathbf{1 4}}$ and oxalic acid, $1,2-\mathrm{C}^{14}$ will be of interest to record here.

Following oral administration of $25 \mu \mathrm{c}$ of glycine $1-\mathrm{C}^{14}$, her urinary oxalate was maximally labeled in the initial ( 0 to 2 hour) specimen. The specific activity values were similar to those found in E.L., who showed the lowest enrichment of the six control subjects (Figure 1). After 30 hours, urinary oxalate contained only trivial quantities of isotope. The cumulative incorporation of $\mathrm{C}^{\mathbf{1 4}}$ into urinary oxalate was 0.047 per cent, a value close to the mean of those obtained in the control subjects (Figure 2).

The miscible pool and the rate of its turnover were determined twice on this patient. On the second day of the study her pool was $39.1 \pm 2.4$ $\mathrm{mg}$ and its turnover $109.7 \pm 6.7 \mathrm{mg}$ per day (Figure 5). On this day her urinary oxalate excretion was $80.6 \mathrm{mg}$ per 24 hours. Subsequently, when her hyperoxaluria had disappeared, her miscible pool was found to be $1.8 \pm 1.0 \mathrm{mg}$ and its turnover $8.2 \pm 3.8 \mathrm{mg}$ per day. Her urinary oxalate excretion on the day of this study (Day 14) was $12.3 \mathrm{mg}$ per 24 hours. 


\section{DISCUSSION}

Physiological disposition of oxalate. Dakin (17) suggested in 1922 that oxalate is a nonessential end product not further metabolized in mammalian tissue. Subsequent studies in animals $(4,18,19)$ and the present studies in man have shown that labeled oxalate is not significantly converted to respiratory $\mathrm{CO}_{2}$, and that an intravenous tracer of labeled oxalate is almost quantitatively excreted in urine.

Biosynthesis of oxalate. Ratner, Nocita and Green (3), Weinhouse and Friedmann (4), and Nakada and Weinhouse (5) have shown in animal studies in vivo and in vitro that glycine may be converted to oxalic acid, via glyoxylic acid. Glycine is converted to glyoxylic acid by glycine oxidase, and possibly as a by-product of transamination with $\alpha$-ketoglutaric acid, a reaction whose equilibrium, however, lies far toward glycine. Glyoxylic acid is converted to oxalic acid by enzymes which are less well understood. One may be xanthine (aldehyde) oxidase (20); another, possibly a mutase, also exists (3). Glyoxylic acid is the only known direct precursor of oxalic acid in mammalian systems. Glycolic acid is readily converted to glyoxylic acid by a flavoprotein, glycolic oxidase (21), and sparingly by lactic dehydrogenase and DPN (5). The pathway by which ascorbic acid $(4,16)$ contributes carbon atoms to oxalic acid is not known. In bacterial systems (22), oxalosuccinic acid, oxaloacetic acid and $\beta$-ketoadipic acid also serve as precursors of oxalic acid.

In the control subjects, 0.03 to 0.08 per cent of glycine $1-\mathrm{C}^{14}$ was converted to oxalic acid. The normal urinary excretion of oxalic acid (mean 22 $\mathrm{mg}$ ) approximates 0.03 to 0.08 per cent of the turnover of the first metabolic glycine pool in man, estimated to be about 0.5 to $1 \mathrm{~g}$ per $\mathrm{kg}$ per day $(23,24)$, or 35 to $70 \mathrm{~g}$ per $70 \mathrm{~kg}$ man per day. Thus, glycine is at least a major precursor of urinary oxalate in normal persons, but the apparent correspondence of values given above should not be stressed unduly, for there is also evidence that an appreciable percentage of urinary oxalate comes from precursors other than glycine. Crawhall, Scowen, de Mowbray and Watts (25) studied a single control subject with glycine 1-C $\mathrm{C}^{13}$, and concluded that at least half of the urinary oxalate was not derived from glycine in this subject.

In the present studies urinary oxalate was labeled considerably in excess of urinary hippurate. When no sodium benzoate is administered, urinary hippurate and urinary free glycine are comparably labeled within a few hours following administration of glycine $\mathrm{N}^{15}$ or $\mathrm{C}^{13}$ (25). The work of Gray and Neuberger (26) and of Arnstein and Neuberger (27) suggests that large doses of benzoate stimulate synthesis de novo of new glycine, or mobilize glycine from pools not ordinarily in rapid equilibrium with the pool from which hippurate derives its glycine. Benzoate loading probably explains why hippurate glycine was less highly labeled than oxalate in the present studies, whereas in the studies of Crawhall and associates (25) free glycine (and presumably hippurate also) was more highly labeled than was oxalate. Finally, the studies reported herein offer additional evidence for the existence of multiple metabolic pools of glycine in poor equilibrium one with another, as previously suggested by studies of a number of other workers $(14,27,28)$.

The miscible pool of oxalate and its biological turnover. The isotopic dilution technique for determination of the pool and turnover of a substance is based upon a number of assumptions and is subject to limitations which have been discussed in detail previously (29). In the present study the major limitations are two: 1) the relatively large fraction of the injected tracer which is rapidly excreted in urine, and 2) the small quantity of oxalate present in 2-or 4-hour urine specimens. The first problem has been approached by eliminating from calculations the labeled oxalate which was excreted without mixing with the pool. The second problem was minimized by employing the average of replicate analyses.

The values shown in Table $I$ for the miscible pool, biological half-time and turnover of oxalate in the body are in reasonably close agreement in three control subjects. The turnover values are in satisfactory agreement with urinary excretion data, although the turnover values tended to be a little larger, both in controls and in the hyperoxaluric subject. Animal studies suggest that some endogenous oxalate is excreted in the feces, but the urinary recovery of labeled oxalate of 94 per cent suggests that nonrenal excretion of en- 
dogenous oxalate is not a large fraction in normal subjects. Since only 90 per cent of oxalate $C^{14}$ was recovered in N.M. when her oxalate pool was large, whereas 99 per cent was recovered when it was small, the possibility remains that a larger fractional nonrenal disposal of oxalate occurs in the presence of expanded body stores of oxalate.

Hyperoxaluria. In C.B., the incorporation of glycine $1-\mathrm{C}^{14}$ into urinary oxalate was 0.22 per cent, a value about fourfold greater than the mean control value. This patient's urinary oxalate excretion was four- to fivefold greater than the mean normal value. Thus it appears that about the same percentage of urinary oxalate was derived from glycine in C.B. as in controls. Crawhall, Scowen and Watts (28) reached a similar conclusion in two hyperoxaluric subjects given glycine $1-C^{13}$. These results, considered together with evidence in vitro that oxalate synthesis from glycine becomes appreciable only when the glyoxylic acid pool is greatly expanded, suggest that a block in glyoxylic acid metabolism may exist in primary hyperoxaluria, possibly of glyoxylicglutamic transaminase (30) or of glyoxylic dehydrogenase (31). Either block (Figure 6) could account for overproduction of oxalate from more than one precursor of its obligatory intermediary, glyoxylic acid (32).

In N.M. the incorporation study was performed at a time when the miscible pool and the daily excretion of oxalate were declining and approaching normal values (Day 5). The metabolic process which had led to hyperoxaluria had inadvertently been corrected, and the possibility that oxalate had previously been overproduced from glycine is not excluded. What relationship, if any, the hyperoxaluria demonstrated in this subject bears to that found in patients with primary hyperoxaluria and oxalosis is obscure at present. Secondary

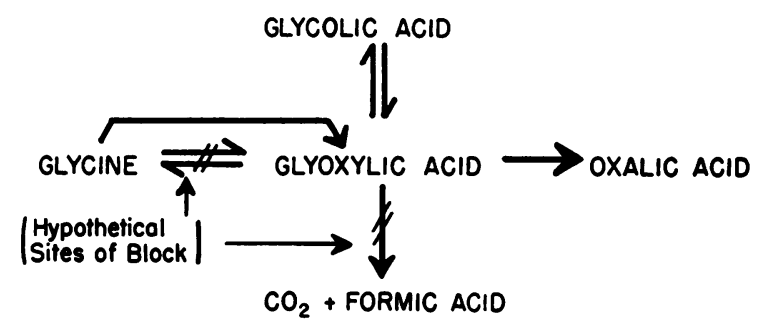

Fig. 6. Possible sites of hypothetical BLock IN PRIMARY HYPEROXALURIA. hyperoxaluria is known to occur in man in sarcoid and hepatic cirrhosis (33) and in animals which are deficient in pyridoxine (34). Additional studies are required to elucidate the nature of the metabolic or absorptive defect responsible for the inconstant hyperoxaluria in this subject.

\section{SUM MARY}

1. In five control subjects, from 0.027 to 0.081 per cent of a tracer dose of glycine $1-\mathrm{C}^{14}$ appeared in urinary oxalate, apparently by a fairly direct biosynthetic route. The sequence, glycine $\longrightarrow$ glyoxylate $\longrightarrow$ oxalate, is known in animals.

2. The miscible pool of oxalate ranged from 4.9 to $8.6 \mathrm{mg}$ in three control subjects; its turnover ranged from 34 to $63 \mathrm{mg}$ per day. The latter values agreed satisfactorily with excretion values. Labeled oxalate was not catabolized to $\mathrm{CO}_{2}$, and was recovered almost quantitatively ( 89 to 99 per cent) in urine.

3. In one hyperoxaluric subject, 0.22 per cent of a glycine $1-\mathrm{C}^{14}$ tracer appeared in urinary oxalate, a value four times the mean control value. In a second patient, the miscible pool of oxalate declined from 39.1 to $1.8 \mathrm{mg}$ and its turnover from 109.7 to $8.2 \mathrm{mg}$ per day during the study period. The nature of the metabolic defect in this patient, who incorporated glycine into oxalate normally, is obscure.

\section{REFERENCES}

1. Wyngaarden, J. B., and Verner, J. V. The biosynthesis of oxalate from glycine $1-\mathrm{C}^{\mathbf{1 4}}$ in man. Clin. Res. 1958, 6, 267.

2. Elder, T. D., and Wyngaarden, J. B. The synthesis and turnover of oxalic acid in normal and hyperoxaluric subjects (abstract). J. clin. Invest. 1959, 38, 1001.

3. Ratner, S., Nocita, V., and Green, D. E. Glycine oxidase. J. biol. Chem. 1944, 152, 119.

4. Weinhouse, S., and Friedmann, B. Metabolism of labeled 2-carbon acids in the intact rat. J. biol. Chem. 1951, $191,707$.

5. Nakada, H. I., and Weinhouse, S. Studies of glycine oxidation in rat tissues. Arch. Biochem. 1953, 42, 257.

6. Hellman, L., and Burns, J. J. Metabolism of L-ascorbic-1-C ${ }^{14}$ acid in man. Fed. Proc. 1955, 14, 225.

7. Burns, J. J. Biosynthesis of L-ascorbic acid; basic defect in scurvy. Amer. J. Med. 1959, 26, 740.

8. Lamden, M. P., and Chrystowski, G. A. Urinary oxalate excretion by man following ascorbic acid ingestion. Proc. Soc. exp. Biol. (N. Y.) 1954, 85, 190. 
9. Andrews, J. C., and Viser, E. T. The oxalic acid content of some common foods. Food Res. 1951, 16, 306.

10. Robinson, C. V. Windowless, flow type proportional counter for counting $C^{14}$. Science 1950, 112, 198.

11. Archer, H. E., Dormer, A. E., Scowen, E. F., and Watts, R. W. E. Studies on the urinary excretion of oxalate by normal subjects. Clin. Sci. 1957, 16, 405.

12. Burns, J. J., Burch, H. B., and King, C. G. The metabolism of $1-\mathrm{C}^{14}-\mathrm{L}$-ascorbic acid in guinea pigs. J. biol. Chem. 1951, 191, 501.

13. Quick, A. J. Clinical application of hippuric acid and prothrombin tests. Amer. J. clin. Path. 1940, $10,222$.

14. Benedict, J. D., Kalinsky, H. J., Scarrone, L. A., Wertheim, A. R., and Stetten, DeW., Jr. The origin of urinary creatine in progressive muscular dystrophy. J. clin. Invest. 1955, 34, 141.

15. Solomon, A. K. Equations for tracer experiments. J. clin. Invest. 1949, 28, 1297.

16. Wyngaarden, J. B., and Stetten, DeW., Jr. Uricolysis in normal man. J. biol. Chem. 1953, 203, 9.

17. Dakin, H. D. Oxidations and Reductions in the Animal Body, 2nd ed. London, Longmans, Green, 1922.

18. Curtin, C. O., and King, C. G. The metabolism of ascorbic acid $1-\mathrm{C}^{14}$ and oxalic acid- $\mathrm{C}^{14}$ in the rat. J. biol. Chem. 1955, 216, 539.

19. Brubacher, G., Just, M., Bodur, H., and Bernhard, K. Zur Biochemie der Oxalsaure. I. Schicksal und Halbwertszeit im Organismus der Ratte; Abbau durch Aspergillus niger. Hoppe-Seylers Z. physiol. Chem. 1956, 304, 173.

20. Booth, V. H. The, specificity of xanthine oxidase. Biochem. J. 1938, 32, 494.

21. Kun, E., Dechary, J. M., and Pitot, H. C. The oxidation of glycolic acid by a liver enzyme. J. biol. Chem. 1954, 210, 269.
22. Jakoby, W. B., and Bhat, J. V. Microbial metabolism of oxalic acid. Bact. Rev. 1958, 22, 75.

23. Crawhall, J. C., and Watts, R. W. E. The free glycine metabolic pool in man. Biochem. J. 1958, 69, 22P.

24. Watts, R. W. E., and Crawhall, J. C. The first glycine metabolic pool in man. Biochem. J. 1959, 73, 277.

25. Crawhall, J. C., Scowen, E. F., de Mowbray, R. R., and Watts, R. W. E. Conversion of glycine to oxalate in a normal subject. Lancet 1959, 2, 810.

26. Gray, C. H., and Neuberger, A. Studies in congenital porphyria. I. Incorporation of ${ }^{15} \mathrm{~N}$ into coproporphyrin, uroporphyrin, and hippuric acid. Biochem. J. 1950, 47, 81.

27. Arnstein, H. R. V., and Neuberger, A. Hippuric acid synthesis in the rat. Biochem. J. 1951, 50, 154.

28. Crawhall, J. C., Scowen, E. F., and Watts, R. W. E. Conversion of glycine to oxalate in primary hyperoxaluria. Lancet 1959, 2, 806.

29. Peterson, R. E., and Wyngaarden, J. B. The miscible pool and turnover rate of hydrocortisone in man. J. clin. Invest. 1956, 35, 552.

30. Cammarata, P., S., and Cohen, P. P. The scope of the transamination reaction in animal tissues. J. biol. Chem. 1950, 187, 439.

31. Nakada, H. I., and Sund, L. P. Glyoxylic acid oxidation by rat liver. J. biol. Chem. 1958, 233, 8.

32. Wyngaarden, J. B., and Elder, T. D. Primary hyperoxaluria and oxalosis in Metabolic Basis of Inherited Disease, J. B. Stanbury, J. B. Wyngaarden and D. S. Frederickson, Eds. New York, McGraw-Hill. In press.

33. Dempsey, E. F., Forbes, A. P., Melick, R. A., and Henneman, P. H. Urinary oxalate excretion. Metabolism 1960, 9, 52.

34. Gershoff, S. N., Faragalla, F. F., Nelson, D. A., and Andrews, S. B. Vitamin $B_{6}$ deficiency and oxalate nephrocalcinosis in the cat. Amer. J. Med. 1959, 27, 72. 